\title{
Выделение изоферментов сукцинатдегидрогеназы из щитков семян кукурузы методом ионообменной хроматографии
}

\author{
Федорин Д.Н., Карабутова Л.А., О.Х. Флорес К., Епринцев А.Т. \\ ФГБОУ ВО «Воронежский государственньй университет», Воронеж
}

Поступила в редакцию 6.07.2017 г.

\begin{abstract}
С помощью метода ионообменной хроматографии на колонке с ДЕАЕ-целлюлозой получены электрофоретически гомогенные препараты сукцинатдегидрогеназы (СДГ, КФ 1.3.99.1) из щитков семян кукурузы с удельной активностью 0.041 Е/мг белка (для первой формы), 0.11 Е/мг белка (для второй формы), 0.03 Е/мг белка (для третьей формы) и 0.037 Е/мг белка (для четвертой формы); выходом $1.6,7,1.1$ и 3.1\%. Степень очистки для изоферментов СДГ составила 2.56, 6.88, 1.88 и 2.31 раза соответственно. Показано, что все полученные препараты СДГ электрофоретически гомогенные, о чем свидетельствуют результаты универсального окрашивания на белок с помощью нитрата серебра.

Ключевые слова: сукцинатдегидрогеназа, изоформы, ионообменная хроматография, электрофорез, кукуруза.
\end{abstract}

\section{Isolation of isoenzymes of succinate dehydrogenase from corn seed by ion exchange chromatography}

\author{
Fedorin D.N., Karabutova L.A., O. Kh. Flores K., Eprintsev A.T. \\ Voronezh State University, Voronezh
}

Succinate dehydrogenase is a complex enzyme complex that ensures the flow of energy and constructive metabolism. In a number of plant organisms, such as arabidopsis and corn, it is found that there are 4 forms of this enzyme that participate in the cycle of tricarboxylic acids, electron transport chain, gluconeogenesis and amino acids metabolisms. Investigation of the mechanisms of regulation of isoenzymes succinate dehydrogenase, including at the level of metabolites of the cell, is an important task, as it provides a delicate control over the course and redistribution of metabolic cell streams, depending on its needs. Since the change in the spatial organization of the configuration of the protein molecule ultimately determines its functional properties, the necessary implementation of metabolic fluxes.

The study of the isoenzyme spectrum of succinate dehydrogenase in corn seed shields by the method of polyacrylamide gel electrophoresis followed by specific staining for SDH activity showed the presence of four forms with different electrophoretic mobility, probably performing different functions in the cell. To obtain a highly purified SDH preparation from the corn seed shields, a 4-step purification was carried out. As a determining purification stage, ion-exchange chromatography was carried out, which made it possible to separate the individual forms of the enzyme under study in an electrophoretically homogeneous state. The preparations of isoforms of succinate dehydrogenase obtained in the homogeneous state allow further study of their regulatory and kinetic properties, with the aim of establishing mechanisms of regulation of the intensity of oxidative and constructive metabolism at the level of succinate dehydrogenase.

Keywords: succinate dehydrogenase, isoforms, ion-exchange chromatography, electrophoresis, corn. 


\section{Введение}

Одной из ключевых реакций цикла Кребса является реакция окисления сукцината до фумарата, катализируемая сукцинатдегидрогеназой (СДГ), единственным ферментом цикла трикарбоновых кислот, встроенным во внутреннюю мембрану митохондрий. СДГ - компонент не только цикла Кребса, но и электрон-транспортной цепи (ЭТЦ) митохондрий, поэтому его регуляция связана с функционированием сразу двух ключевых процессов $[1,2]$. Наличие множественных метаболических реакций, связанных с одним субстратом - сукцинатом, позволяет осуществлять гибкий контроль соотношения метаболических потоков для обеспечения нормального протекания гомеостаза в клетке [3]. Поэтому очень важна регуляция окислительных и синтетических процессов на уровне ферментативных систем, в том числе сукцинатдегидрогеназы. Ее высокий генетический полимофизм позволяет формировать до четырех изоферментов СДГ-системы, что свидетельствует о ее важной роли в осуществлении регуляции метаболизма растений $[4,5]$.

Исследование кинетических и регуляторных характеристик отдельных изоферментов сукцинатдегидрогеназы позволяет определить функциональную роль каждого из них в обеспечении метаболических потоков клетки в зависимости от ее потребности в энергии и биосинтетических субстратов. Для исследования характеристик сукцинатдегидрогеназы необходимо получение гомогенных препаратов, обеспечивающих возможность исследования их характеристик. В связи с этим целью работы явилось получение высокоочищенных препаратов изоферментов сукцинатдегидрогеназы из щитков семян кукурузы с помощью ионообменной хроматографии.

\section{Эксперимент}

В качестве объекта исследования использовали 2-дневные растения кукурузы (Zea mays L.), выращенные гидропонными способом при 12-часовом световом дне и интенсивности 25 Дж/м². Активность СДГ определяли в щитках и проростках кукурузы на спектрофотометре T70+UV-VIS Spectrophotometer (PG Instruments Limited, Англия). Активность фермента рассчитывали по падению оптической плотности среды при длине волны 600 нм, обусловленному обесцвечиванием 2,6дихлорфенолиндофенола в ходе его восстановления. За единицу ферментативной активности принимали количество фермента, образующего 1 мкмоль продукта за 1 мин при $25^{\circ} \mathrm{C}$.

Очистку фермента осуществляли в несколько стадий при температуре $0-4^{\circ} \mathrm{C}$. Стадия 1. Гомогенизация. Навеску растительного материала (5 г) гомогенизировали в соотношении 1:5 со средой выделения следующего состава: 50 мМ Трис- $\mathrm{HCl}$ буфер (pН 7.5), содержащий 1 мМ ЭДТА, $10 \mathrm{MM} \mathrm{KCl,} 1 \mathrm{MM} \mathrm{MgCl}, 0.4 \mathrm{M}$ сахарозы. Стадия 2. Полученный гомогенат фильтровали через 4 слоя марли и центрифугирова-ли в течение 5 мин. при $3000 \mathrm{~g}$. Надосадочную жидкость центрифугировали в течение 15 мин при $12000 \mathrm{~g}$. Осадок, содержащий в основном митохондрии и микротельца, ресуспендировали в $1 \mathrm{~cm}^{3}$ среды, содержащей 10мМ фосфатный буфер (pH 7.8), 0.01\% тритон X-100, 20мМ сукцинат натрия. Стадия 3. Фракционирование сульфатом аммония с последующей гель-фильтрацией на колонке с сефадексом G25. К супернатанту добавляли кристаллический сульфат аммония до $20 \%$ насыщения. Центрифугировали 20 мин. при 15000g. Супернатант вновь фракционировали до $60 \%$ насыщения сульфатом аммония и вновь центрифугировали 20 мин при $15000 \mathrm{~g}$. Осадок ресуспендировали в 1-2 см ${ }^{3}$ среды, содержащей 10 мМ фосфатный буфер (pH 7.8), 0.01\% тритон X-100, 20 мМ сукцинат 
натрия. Полученный ферментативный препарат наносили на колонку, заполненную сефадексом G-25 для освобождения от низкомолекулярных примесей. Элюцию осуществляли 10 мМ фосфатным буфером (pH 7.8), содержащим 20 мМ сукцинат натрия, со скоростью 15-20 мл в час. Стадия 4. Ионообменная хроматография. Фермент наносили на колонку с ДЭАЭ-целлюлозой, предварительно уравновешенную 30мМ фосфатным буфером (рН 7.8), содержащим $30 \mathrm{MM} \mathrm{KCl} \mathrm{[6].}$ Фракции собирали вручную по $1 \mathrm{~cm}^{3}$ в градуированные микропробирки Eppendorf. При нанесении препарата на колонку фермент связывался с носителем. Поскольку фермент заряжен отрицательно, а колонка положительно, между ними возникает электростатическое взаимодействие. Чем сильнее заряжен белок, тем сильнее его взаимодействие с сорбентом. Разделение белков происходит путем десорбции их с носителя раствором, ионной силы которого достаточно для разрыва электростатических связей фермента и сорбента. Фермент десорбировали с колонки градиентом концентрации $\mathrm{KCl}$ в среде элюирования. Наиболее оптимальным для десорбции фермента был линейный градиент концентрации $\mathrm{KCl}$ от 0.03 до $0.2 \mathrm{M}$, среда десорбирования представляла собой $20 \mathrm{мM}$ фосфатный буфер (pH 6.2), содержащий 20 мМ сукцината. Активность фермента обнаруживалась под действием ионной силы раствора, содержащего $0.075 \mathrm{M} \mathrm{KCl}$ в среде элюирования, достаточной для отрыва сукцинатдегидрогеназы от ДЭАЭ-целлюлозы.

Электрофоретические исследования белков проводили в 7,5\% полиакриламидном геле (ПААГ) [7]. Универсальное окрашивание белков в гелях осуществляли с помощью $\mathrm{AgNO}_{3}[8]$, для специфической идентификации СДГ использовали тетразолиевый метод со средой следующего состава: калий-фосфатный буфер $0.1 \mathrm{M}(\mathrm{pH}$ 7.5), 0.1 М сукцинат натрия, $0.5 \mathrm{mг} / \mathrm{cm}^{3}$ нитросинего тетразолия и $1 \mathrm{Mг} / \mathrm{cm}^{3}$ феназин метасульфата. Полученные данные обрабатывали с использованием статистических критериев. Обсуждаются статистически достоверные различия при р<0.05 [9].

\section{Обсуждение результатов}

С целью получения чистого ферментативного препарата была проведена 5-ти стадийная очистка СДГ из листьев кукурузы. Результаты типичной очистки представлены в таблице 1.

Таблица 1. Очистка сукцинатдегидрогеназы из щитков семян кукурузы $(\mathrm{n}=3, \mathrm{p}<0.05)$

\begin{tabular}{|c|c|c|c|c|c|c|}
\hline Стадия & $\begin{array}{c}\text { Объем } \\
\text { фракций, } \\
\text { см}^{3}\end{array}$ & $\begin{array}{c}\text { Количество } \\
\text { белка, мг }\end{array}$ & $\begin{array}{c}\text { Общая ак- } \\
\text { тивность, } \\
\text { E }\end{array}$ & $\begin{array}{c}\text { Удельная ак- } \\
\text { тивность, } \\
\text { Е/мг белка }\end{array}$ & $\begin{array}{c}\text { Выход* } \\
\%\end{array}$ & $\begin{array}{l}\text { Степень } \\
\text { очистки }\end{array}$ \\
\hline Гомогенизация & 15 & 62.54 & 0.9984 & 0,016 & 100 & 1 \\
\hline $\begin{array}{c}\text { Фракционирование } \\
\text { сульфатом аммо- } \\
\text { ния } \\
20-60 \%\end{array}$ & 3 & 6.774 & 0.192 & 0.028 & 19.2 & 1.75 \\
\hline $\begin{array}{c}\text { Гель-фильтрация на } \\
\text { сефадексе } \\
\text { G-25 }\end{array}$ & 4 & 3.982 & 0.084 & 0.021 & 8.4 & 1,31 \\
\hline $\begin{array}{l}\text { Хроматография на } \\
\text { ДЭАЭ-целлюлозе }\end{array}$ & $\begin{array}{l}\text { 1) } 2 \\
\text { 2) } 2 \\
\text { 3) } 2 \\
\text { 4) } 2\end{array}$ & $\begin{array}{l}0.387 \\
0.637 \\
0.349 \\
0.840 \\
\end{array}$ & $\begin{array}{l}0.016 \\
0.067 \\
0.011 \\
0.031\end{array}$ & $\begin{array}{l}0.041 \\
0.110 \\
0.030 \\
0.037 \\
\end{array}$ & $\begin{array}{l}1.6 \\
7.0 \\
1.1 \\
3.1 \\
\end{array}$ & $\begin{array}{l}2.56 \\
6.88 \\
1.88 \\
2.31 \\
\end{array}$ \\
\hline
\end{tabular}

*Выход рассчитывался как доля (\%) активности сукцинатдегидрогеназы на данной стадии от активности фермента в гомогенате, которая принимается за 100\%. Степень очистки рассчитывалась как отношение удельной активности сукцинатдегидрогеназы на данной стадии к удельной активности фермента в гомогенате. 
Первой стадией очистки было получение гомогената с использованием среды, содержащей сахарозу, с целью экстракции неразрушенных митохондрий. На второй стадии нами была получена фракция митохондрий методом дифференциального центрифугирования, при этом удельная активность фермента возросла более чем в 6 раз.

После солюбилизации фермента с мембраны детергентом тритон X-100 следовало фракционирование сульфатом аммония в пределах 20-60\% насыщения. Для обессоливания ферментативного препарата использовали сефадекс G-25. Общая активность составила 0.084 ед., тогда как удельная активность была 0.021 ед./мг белка. Степень очистки на данной стадии соответствовала 15.7 с выходом $8 \%$.

В качестве определяющей стадии очистки осуществляли ионообменную хроматографию. Элюцию фермента в колонки осуществляли линейным градиентом хлорида калия от 50 до 200 мМ и содержанием сукцината в среде 20 мМ. После стадии ионообменной хроматографии на ДЭАЭ-фрактогеле сукцинатдегидрогеназа из щитков кукурузы была очищена с разной степенью для каждой из фракций. СДГ1 имеет удельную активность 0.041 Е/мг белка, при этом степень очистки составила 2.56 раза с выходом 1.6\%. Для СДГ2 удельная активность составила 0.11 Е/мг белка, степень очистки 6.88 раза и выходом 7\%. Препарат СДГЗ имел удельную активность 0.03 Е/мг белка, степень очистки 1.88 раза и выход $1.1 \%$. Для формы СДГ4 удельная активность была 0.037 Е/мг белка, степень очистки 2.31 раза с выходом $3.1 \%$.

Применение четырехстадийной очистки позволило получить высокоочищенные препараты сукцинатдегидрогеназы из щитков кукурузы на 2 день прорастания семян. Электрофорез в 7.5\% ПААГ с последующей окраской геля нитратом серебра показал гомогенность полученных ферментативных препаратов, о чём свидетельствует наличие только одной белковой полосы в каждой пробе (рис. 1).

Полосы после специфического проявления на активность СДГ и окрашивания на белок совпадают и имеют соответственно $\mathrm{R}_{\mathrm{f}}$ равное 0.22 для первой формы, $\mathrm{R}_{\mathrm{f}}$ 0.27 для второй формы, $\mathrm{R}_{\mathrm{f}}$ равное 0.34 для третьей и $\mathrm{R}_{\mathrm{f}} 0.42$ - для четвертой. Таким образом, было установлено, что в щитке кукурузы присутствуют 4 формы фермента, поэтому можно утверждать, что полученные ферментативные препараты гомогенны (рис. 1).

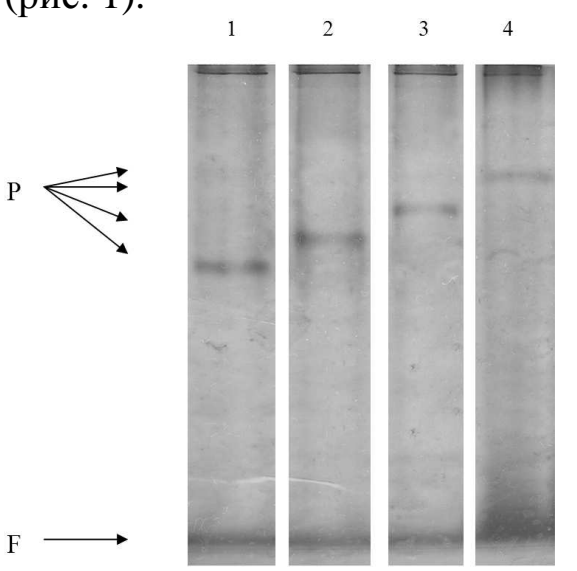

Рис. 1. Электрофорез на гомогенность сукцинатдегидрогеназы из щитков кукурузы (проявление с нитратом серебра). 1 СДГ1, 2 - СДГ2, 3 - СДГ $3,4-$ СДГ 4. P белковая полоса. F - фронт красителя

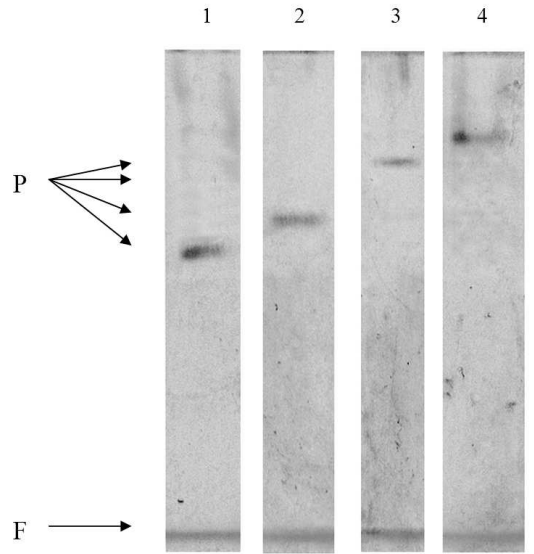

Рис. 2. Электрофореграмма на специфическое проявление сукцинатдегидрогеназы из щитков кукурузы. 1 - СДГ 1,2 - СДГ2, 3

- СДГЗ, 4 - СДГ4.

$\mathrm{P}$ - белковые полосы. F - фронт красителя.

С помощью специфического проявления электрофореграмм, содержащих препараты очищенных изоформ СДГ, было установлено, что белковые зоны облада- 
ли сукцинатдегидрогеназной активностью (рис. 2). Специфическое проявление СДГ активности в гелях, осуществлённое тетразолиевым методом, показало наличие четырех изоформ фермента с $\mathrm{R}_{\mathrm{f}} 0.22,0.27,0.34$, и 0.42 в щитках кукурузы.

Таким образом, была разработана эффективная схема очистки СДГ из щитков кукурузы, включающая ионообменную хроматографию как основную стадию разделения изоформ. Полученные результаты ранее были получены для изоферментов из листьев кукурузы, где определяющей статьей очистки также являлась ионообменная хроматография [10]. Полученные в гомогенном состоянии препараты изоформ сукцинатдегидрогеназы позволяют в дальнейшем изучить их регуляторные и кинетические свойства с целью установления механизмов регуляции интенсивности окислительного и конструктивного метаболизма на уровне сукцинатдегидрогеназы.

\section{Заключение}

Таким образом, был разработан эффективный способ очистки СДГ из щитков кукурузы, включающий ионообменную хроматографию. В качестве определяющей стадии очистки осуществляли ионообменную хроматографию, позволившую получить четыре формы исследуемого фермента в высокоочищенном состоянии. Показано, что все формы СДГ десорбируются с ДЭАЭ-целлюлозы при разных концентрациях хлорида калия, что может указывать на различие в структурной организации полипептидных компонентов изоформ сукцинатдегидрогеназы.

Электрофоретические исследования полученных с помощью ДЭАЭцеллюлозы изоферментов СДГ показали, что при универсальном проявлении на белок было показано наличие одной полосы в каждом из исследуемых образцов. Следовательно, полученные препараты сукцинатдегидрогеназы являются электрофоретически гомогенными. Специфическое проявление на активность исследуемого фермента тетразолиевым методом подтвердило, что полученные нами препараты обладают сукцинатдегидрогеназной активностью.

\section{Работа выполнена при поддержке Российского научного фонда, Грант № 14-14-00721.}

\section{Список литературы}

1. Епринцев А.Т., Федорин Д.Н., Селиванова Н.В., Ахмад Дж.А. и др. // Известия РАН. Серия биологическая. 2010. № 3. С. 324-332.

2. Pastore D., Trono D., Laus M.N. // J. Biol. Chem. 2001. Vol. 276. pp. 32567-32574.

3. Епринцев А.Т., Федорин Д.Н., Селиванова Н.В. Молекулярные аспекты формирования олигомерной структуры сукцинатдегидрогеназы. Воронеж. 2016. 264 с.

4. Popov V.N., Eprintsev A.T., Fedorin D.N., Igamberdiev A.U. // FEBS Letters. 2010. Vol. 584. pp.199-202

5. Millar A.H., Eubel H., Jänsch L., Kruft V. et al. // Plant Journal of Molecular Biology. 2004. Vol.56. pp. 77-90.
6. Селеменев В.Ф., Рудаков О.Б., Славинская Г.В., Дроздова Н.В. М. ДеЛи принт. 2008. $246 \mathrm{c}$

7. Davis B.J. // Ann. N. Y. Acad. Sci. 1994. Vol. 121. pp. 404-427.

8. Shevchenko A., Wilm M., Vorm O., Mann M. // Anal. Chem. 1996. Vol. 68. pp. 850-858.

9. Лакин Г.Ф. Биометрия. М. Высш. шк. 1990. 351c.

10.Федорин Д.Н., Карабутова Л.А., Покусина Т.А., Епринцев А.Т. // Сорбционные и хроматографические проиессы. 2016. Т. 16. № 4. C. 280-285. 


\section{References}

1. Eprintsev A.T., Fedorin D.N., Selivanova N.V., Akhmad Dzh.A. et al., Izvestiya RAN. Seriya biologicheskaya, 2010, No 3, pp. 324332.

2. Pastore D., Trono D., Laus M.N., J. Biol. Chem., 2001, Vol. 276, pp. 32567-32574.

3. Eprintsev A.T., Fedorin D.N., Selivanova N.V., Molekulyarnyye aspekty formirovaniya oligomernoy struktury suktsinatdegidrogenazy, Voronezh, 2016, $264 \mathrm{p}$.

4. Popov V.N., Eprintsev A.T., Fedorin D.N., Igamberdiev A.U., FEBS Letters, 2010, Vol. 584, pp. 199-202

Федорин Дмитрий Николаевич - к.б.н., кафедра биохимии и физиологии клетки, Воронежский государственный университет, Воронеж, тел.(473)2208877

Карабутова Людмила Александровна - аспирант, кафедра биохимии и физиологии клетки, Воронежский государственный университет, Воронеж, тел.(473)2208877

Флорес Каро Орландо Де Хесус - бакалавр, кафедра биохимии и физиологии клетки, Воронежский государственный университет, Воронеж, тел.(473)2208877

Епринцев Александр Трофимович - д.б.н., проф., кафедра биохимии и физиологии клетки, Воронежский государственный университет, Воронеж, тел.(473)2208877
5. Millar A.H., Eubel H., Jänsch L., Kruft V. et al., Plant Journal of Molecular Biology, 2004, Vol.56, pp. 77-90.

6. Selemenev V.F., Rudakov O.B., Slavinskaja G.V., Drozdova N.V. M., DeLi print, 2008, 246 p.

7. Davis B.J., Ann. N. Y. Acad. Sci., 1994, Vol. 121, pp. 404-427.

8. Shevchenko A., Wilm M., Vorm O., Mann M., Anal. Chem., 1996, Vol. 68, pp. 850-858.

9. Lakin G.F. Biometriya, M., Vyssh. shk., 1990, $351 \mathrm{p}$.

10. Fedorin D.N., Karabutova L.A., Pokusina T.A., Eprintsev A.T., Sorbtsionnye i khromatograficheskiye protsessy, 2016, Vol. 16, No 4, pp. 280-285.

Fedorin Dmitry N. - Ph.D of Biology, Department of Biochemistry and Physiology, Voronezh State University, Voronezh, e-mail: rybolov@ mail.ru

Karabutova Lyudmila A. - post-graduate student, Department of Biochemistry and Cell Physiology, Voronezh State University, Voronezh, e-mail: lyudmilakarabutova@bk.ru

Flores Caro Orlando De Jesus - student, Department of Biochemistry and Cell Physiology, Voronezh State University, Voronezh, e-mail: bc366@bio.vsu.ru

Eprintsev Alexander T. - Doctor of Biology, Department of Biochemistry and Physiology, Voronezh State University, Voronezh, e-mail: bc366@bio.vsu.ru 